\title{
ANALISIS AKUNTABILITAS DAN TRANSPARANSI LAPORAN KEUANGAN LEMBAGA AMIL ZAKAT DI KOTA BANDUNG
}

\author{
Oleh: \\ Elis Mediawati \\ (Dosen Program Studi Akuntansi Universitas Pendidikan Indonesia) \\ Sri Maryati
}

\begin{abstract}
Abstrak
Penelitian ini bertujuan untuk menganalisis pengaruh pandangan masyarakat tentang akuntabilitas dan transparansi laporan keuangan lembaga amil zakat (LAZ) terhadap reliasasi penerimaan zakat. Realisasi penerimaan zakat oleh LAZ yang jauh lebih kecil dibandingkan dengan potensi zakat yang ada disebabkan oleh muzaki lebih memilih untuk membayarkan zakatnya kepada mustahik dibandingkan dengan membayarkannya melalui LAZ. Penelitian ini menggunakan metode penelitian deskriptif kualitatif yang memberikan penjelasan mengenai fenomena realisasi penerimaan zakat yang berbeda jauh dengan jumlah potensi zakat yang ada. Peneliti mengolah data yang ada dari berbagai sudut pandang baik dari sudut pandang muzaki maupun dari sudut pandang amil zakat itu sendiri. Berdasarkan hasil penelitian, dapat ditarik kesimpulan bahwa akuntabilitas dan transparansi laporan keuangan tidak menjadi pertimbangan utama bagi masyarakat dalam menyalurkan zakat.
\end{abstract}

Kata Kunci: Akuntabilitas, Transparansi, LAZ, Zakat, Laporan Keuangan

\section{Latar Belakang}

LAZ bertugas menyalurkan dana zakat dari wajib zakat (muzaki) kepada delapan asnaf (mustahik) yang berhak mendapatkannya. Potensi zakat di Indonesia sangat besar, berikut daftar potensi zakat Indonesia berdasarkan penelitian yang dilakukan sebelumnya:

Tabel 1

Potensi Zakat Indonesia

\begin{tabular}{|c|l|c|}
\hline Tahun & \multicolumn{1}{|c|}{ Sumber } & $\begin{array}{c}\text { Jumlah Potensi Zakat Indonesia } \\
\text { dalam Triliun Rupiah }\end{array}$ \\
\hline 2007 & PIRAC & 9,09 \\
\hline 2007 & Syafii Antonio & 17 \\
\hline 2008 & Kompas & 4,8 \\
\hline 2008 & Ivan Syaftian (UI) & 4,825 \\
\hline
\end{tabular}

Sumber: Josephus Primus, http://nasional.kompas.com (data diolah)

Sedangkan potensi zakat kota Bandung sendiri jika di tinjau dari aspek ekonomis potensinya sangat besar. Dengan jumlah penduduk sebanyak 3,2 juta jiwa (termasuk golongan masyarakat miskin), $97 \%$ atau sekitar 3 juta orang beragama islam. Apabila sebanyak $30 \%$ atau sekitar 1 juta orang menunaikan zakat bisa dirata-ratakan besaran zakat Rp. $100.000,00$ per tahun per jiwa, maka jumlah dana yang terkumpul dalam satu tahun adalah sebanyak 100 milyar. Nominal yang cukup tinggi untuk potensi sebuah kota.

Besarnya potensi zakat di Indonesia sayangnya belum terserap dengan baik oleh lembaga amil zakat yang ada. Terjadi perbedaan yang sangat mencolok antara potensi zakat dan realisasi penerimaannya oleh lembaga. Penyebab terjadinya perbedaan antara potensi dan realisasi ini antara lain adalah masyarakat lebih mernilih memberikan zakatnya secara langsung kepada mustahik. Sebagian besar masyarakat memiliki 
pandangan bahwa jika memberikan zakat langsung kepada mustahik akan mendatangkan ketenangan dibandingkan dengan menitipkannya pada lembaga. Berikut daftar realisasi penerimaan zakat Indonesia dari tahun ke tahun.

Tabel 2

Tabel Realisasi Penerimaan Zakat

\begin{tabular}{|c|c|}
\hline Tahun & Realisasi \\
\hline 2007 & 450 miliar \\
\hline 2008 & 920 miliar \\
\hline 2009 & 1.2 triliun \\
\hline 2010 & 1.5 triliun \\
\hline 2011 & 1.3 triliun \\
\hline
\end{tabular}

Sumber: http://zakat.or.id (data diolah)

Berdasarkan hasil penelitian yang dilakuan oleh Siti Muniroh (2008) Rendahnya tingkat realisasi penerimaan zakat tampaknya berawal dari kurangnya tingkat kepercayaan masyarakat terhadap organisasi pengelola zakat yang ada. Masyarakat menghendaki adanya Organisasi Pengelola Zakat yang akuntabel dan transparan. Adapun definisi Akuntabilitas dan Transparansi menurut KK, SAP, 2005 (dalam Annisaningrum) sebagai berikut, akuntabilitas adalah mempertanggungjawabkan pengelolaan sumber daya serta pelaksanaan kebijakan yang dipercayakan kepada entitas pelaporan dalam mencapai tujuan yang telah ditetapkan secara periodik. Transparansi adalah memberikan informasi keuangan yang terbuka dan jujur kepada masyarakat berdasarkan pertimbangan bahwa masyarakat memiliki hak untuk mengetahui secara terbuka dan menyeluruh atas pertanggungjawaban pemerintah dalam pengelolaan sumber daya yang dipercayakan kepadanya dan ketaatannya pada peraturan perundang- undangan.

Berdasarkan survei nasional yang dilakukan UIN Jakarta dan dipublikasikan dalam demustaine.blogdetik.com oleh Ine Dwiyanti, (2007) ditemukan hasil survei yang melibatkan ribuan responden sebagai berikut:

Tabel 3

Tabel Hasil Survei Nasional

\begin{tabular}{|l|l|}
\hline \multicolumn{1}{|c|}{ Persentasi Hasil } & \multicolumn{1}{|c|}{ Keinginan Responden } \\
\hline $97 \%$ Responden & LAZ bekerja secara akuntabel dan transparan \\
\hline $90 \%$ Responden & $\begin{array}{l}\text { Adanya akses bagi publik untuk melakukan pengawasan terhadap } \\
\text { dana yang dikelola }\end{array}$ \\
\hline Adanya pemuatan laporan keuangan di media massa \\
\hline $88 \%$ Responden & Adanya catatan data mengenai donator \\
\hline $75 \%$ Responden & $\begin{array}{l}\text { Enggan menyalurkan zakat pada LAZ yang tidak dikenal baik } \\
\text { akuntabilitasnya }\end{array}$ \\
\hline $63 \%$ Responden & $\begin{array}{l}\text { Adanya kepastian bahwa dana zakat disalurkan kepada yang } \\
\text { berhak }\end{array}$ \\
\hline
\end{tabular}

Dalam peraturan UU No. 38/1999 memang tidak disebutkan adanya kewajiban bagi Lembaga ataupun badan Amil Zakat untuk melakukan audit secara independen alhasil banyak Lembaga Amil Zakat yang tidak melakukan audit pada laporan keuangan, hanya lembaga amil zakat tertentu yang melakukan audit independen. Hal ini dapat memicu ketidakpercayaan masyarakat terhadap lembaga amil zakat yang ada dan hal ini juga mempengaruhi penerimaan zakat dari masyarakat kepada lembaga amil zakat. 
Majelis Ulama Indonesia (MUI) juga menyatakan bahwa transparansi yang dilakukan oleh lembaga amil zakat masih kurang. Alasannya tidak semua lembaga amil zakat melakukan audit laporan keuangan oleh akuntan publik dan dipublikasikan hasilnya kepada masyarakat, hanya lembaga-lembaga amil zakat tingkat nasional yang melakukan audit dan dipublikasikan. Begitu pula halnya dengan Ketua Umum Badan Amil Zakat Nasional (Baznas), Didin Hafiduddin, (2002) mengatakan, transparansi bisa dilakukan melalui audit independen oleh akuntan publik. Hasilnya kemudian dipublikasikan kepada masyarakat. Hingga tahun 2009 terdapat sekitar 100 lembaga pengelola zakat di Indonesia. Sayangnya, baru 19 lembaga yang melakukan audit independen dan melaporkannya kepada publik secara rutin.

Selama ini baik Baznas, badan amil zakat daerah maupun lembaga amil zakat, baik yang tersertifikasi maupun yang tidak, memiliki aturan masing-masing dalam kegiatan operasionalnya, sehingga terjadi ketidaksinambungan antar lembaga, ada yang melakukan audit, ada yang tidak, bahkan lembaga pengumpul zakat dengan skala kecil, enggan melakukan pencatatan.

Inti dari permasalahan zakat selama ini dapat dikelompokkan menjadi tiga bagian, yakni muzaki, pengelola, dan pengawas (masyarakat itu sendiri). Selama ketiga faktor tersebut berjalan sendiri-sendiri, optimalisasi potensi zakat tidak akan tercapai.

\section{Rumusan Masalah}

Berdasarkan uraian latar belakang penelitian di atas, dapat dirumuskan beberapa permasalahan sebagai berikut:

1. Bagaimanakah pandangan masyarakat tentang akuntabilitas dan transparansi Lembaga Amil Zakat?

2. Apakah pandangan masyarakat tersebut berpengaruh terhadap penerimaan zakat oleh Lembaga Amil Zakat?

\section{Kerangka Pemikiran}

Organisasi pengelola zakat merupakan organisasi publik sehingga akuntabilitas dan transparansi laporan keuangannya merupakan hal yang penting untuk mendapatkan kepercayaan masyarakat. Akuntabilitas dan transparansi merupakan dua dari sepuluh prinsip good governance, prinsip-prinsip tersebut antara lain: (1) Participation (partisipasi); (2) Rule of law (kerangka hukum); (3) Transparency (transparansi); (4) Equality (kesetaraan); (5) Responsiveness (daya tangkap); (6) Strategic vision (wawasan ke depan); (7) Accountability (akuntabilitas); (8) Efficiency and effectiveness (efektif dan efisien); (9) Professionalism (profesionalisme); (10) Consensus orientation (berorientasi pada konsesus.

Di antara ke-sepuluh prinsip tersebut terdapat prinsip yang berkaitan erat antara satu dengan lainnya dan ada pula prinsip yang merupakan prakondisi agar prinsip yang lain dapat berjalan. Pada kenyataannya, sulit untuk menerapkan semua prinsip tersebut sekaligus. Oleh karena itu perlu dilakukan pemrioritasan dalam pelaksanaan prinsipprinsip atau karakteristik good governance tersebut agar good governance dapat terwujud pada berbagai bidang pembangunan.

Dari beberapa prinsip yang dikemukaan berbagai intuisi terlihat bahwa prinsip yang melandasi good governance sangat bervariasi dari satu institusi ke institusi lainnya. Beberapa hal mempengaruhi apa yang diadopsi setiap institusi. Misalnya suatu departemen hanya memilih tiga dari sepuluh prinsip tersebut. Diantara berbagai berbagai prinsip yang adopsi paling tidak ada sejumlah prinsip yang disepakati oleh institusiinstitusi tersebut sebagai karakteristik good governance, yang diantaranya adalah prinsip akuntabilitas dan transparansi. Walaupun prinsip ini adalah dua prinsip yang berbeda, 
pada pelaksanaannya akuntabilitas dan transparansi adalah prinsip yang berkaitan. Kedua prinsip tersebut tidak dapat berjalan sendiri-sendiri karena terdapat hubungan yang sangat erat dan saling mempengaruhi.

Akuntabilitas sebetulnya timbul sebagai konsekuensi logis atas adanya hubungan antara agent (manajemen) dan principal (pemilik) (agent-principal relationship). Principal dalam hal ini memberikan kewenangan penuh pada agent untuk melakukan aktivitas operasional organisasi. Sebagai konsekuensi atas wewenang ini, maka agent harus mempertanggung-jawabkan aktivitasnya terhadap principal. Gray, Owen, dan Maunders (dalam Iwan Triyuwono, 2000) mendefinisikan akuntabilitas sebagai principal melepaskan kontrol atas sumberdaya kepada agent, memberikan instruksi atau ekspektasi tentang penggunaan sumberdaya. Kemudian agent bertanggung jawab atas pelaksanaan aktivitas dan pemberian pertanggungjawaban atas aktivitas tersebut. Gray et.al (1988,1991), Patton (1992) (dalam Harahap, 2008) mengungkapkan bahwa accountability bukan hanya dapat mempertanggungjawabkan secara finansial, secara formal tetapi lebih luas dari itu harus mampu meningkatkan tanggung jawab kepada masyarakat, pemerintah, dan kepatuhan pada peraturan. Bukan hanya itu tetapi perusahaan harus bertanggung jawab pada kepentingan karyawan, lingkungan, sistem yang mendukung kebenaran, kebaikan, etika, penegakan hukum, menciptakan lingkungan kasih sayang, ketaatan pada peraturan, loyalitas pada keadilan, dan sebagainya.

Agent-principal relationship dalam penelitian ini (yaitu: dalam konteks lembaga keuangan syariah) lebih luas dibanding dengan pengertian di atas. Keluasan itu terletak pada pengertian principal. Dalam pengertian yang umum seperti di atas, principal adalah para pemegang saham (stockholders). Ini berarti bahwa manajemen (OPZ) harus bertanggung-jawab atas penggunaan sumberdaya zakat sehingga organisasi pengelola zakat mempunyai kewajiban untuk melaksanakan semua transaksi bisnisnya sesuai dengan aturan dan prinsip-prinsip syariah.

Pernyataan di atas juga didukung oleh Undang-undang No. 38 tahun 1999 Bab VI tentang Pengawasan, khususnya pasal 18 ayat (4) dan pasal 20 yang mengatakan bahwa diperlukannya pengawasan terhadap pelaksanaan tugas Lembaga pengelola zakat, dan dalam pengawasan tersebut akuntan publik dan masyarakat dapat berperan aktif.

Penelitian tentang penyelenggaraan akuntansi untuk lembaga amil zakat telah dilakukan sebelumnya yang telah dilakukan oleh Nidya (2009) menyebutkan bahwa lembaga amil zakat di Bandung telah menerapkan pengukuran laporan keuangan berdasarkan PSAK Nomor 45 dengan baik.

Akuntabilitas merupakan kewajiban untuk memberikan pertanggungjawaban atau menjawab dan menerangkan kinerja atas tindakan seseorang/badan hukum/pimpinan suatu organisasi kepada pihak yang memiliki hak atau kewenangan untuk meminta keterangan atau pertanggungjawaban. Sehingga masyarakat dapat menilai apakah suatu organisasi publik dapat dikatakan akuntabel atau tidak. Masyarakat juga mengharapkan adanya transparansi dalam penyelenggaraan suatu entitas publik. Adanya audit independen merupakan salah satu bentuk dari usaha LAZ dalam menyelenggarakan kegiatan usaha yang akuntable dan transparan.

Dengan adanya laporan keuangan yang akuntabel dan transparan diharapkan dapat meningkatkan kepercayaan masyarakat kepada LAZ sehingga penyerapan potensi zakat masayarakat, karena masyarakat lebih memilih untuk menyalurkan zakatnya melalui LAZ yang dapat mendistribusikan zakat tersebut tepat sasaran. Hal ini sesuai dengan pengukuhan LAZ Bab III yang menyebutkan bahwa setiap LAZ yang ingin dikukuhkan harus memiliki daftar muzaki dan mustahiq, sehingga mempermudah lembaga pengelola dalam mendistribusikan zakat yang akan disalurkan. 
Dalam sebuah penelitian mengenai persepsi masyarakat terhadap Badan Amil Zakat yang dilakukan oleh Siti Muniroh (2008), disebutkan bahwa terdapat perbedaan pendapat di antara muzaki mengenai persepsi terhadap Badan Amil Zakat yaitu ada yang setuju membayar zakat melalui Badan Amil Zakat karena membayar zakat melalui Badan Amil Zakat itu tidak terasa mengeluarkan zakat karena tinggal memotong gaji dan kita ikut menyukseskan gerakan pengentasan kemiskinan. bagi yang tidak setuju membayar zakat melalui Badan Amil Zakat hal ini di karenakan kurang percaya dengan Badan Amil Zakat karena belum tentu disalurkan sesuai dengan kriteria yang ditentukan, kalau menyalurkan zakat secara langsung itu lebih cepat dan mudah, lebih yakin disalurkan secara langsung karena penyalurannya akan tepat sasaran.

Adanya rasa kurang percaya dari masyarakat ini perlu segera diatasi oleh lembaga pengelola zakat demi meningkatkan penyerapan potensi zakat. Lembaga pengelola perlu mengetahui keinginan dan tuntutan masyarakat agar mampu menjalankan amanah yang diberikan muzaki.

Teori asimetri informasi (information asymetry) berbicara mengenai ketidakpercayaan masyarakat terhadap organisasi sektor publik lebih disebabkan oleh kesenjangan informasi antara pihak manajemen yang memiliki akses langsung terhadap informasi dengan pihak konstituen atau masyarakat yang berada di luar manajemen. Pada tataran ini, konsep mengenai akuntabilitas dan aksesibilitas menempati kriteria yang sangat penting terkait dengan pertanggungjawaban organisasi dalam menyajikan, melaporkan dan mengungkap segala aktifitas kegiatan serta sejauh mana laporan keuangan memuat semua informasi yang relevan yang dibutuhkan oleh para pengguna dan seberapa mudah informasi tersebut diakses oleh masyarakat.

Adanya regulasi mengenai pengelolaan keuangan Organisasi Pengelola Zakat, seperti yang termaktub dalam undang-undang Zakat No.38 Tahun 1999 Bab VIII pasal 21 Ayat 1 yang dikuatkan oleh KMA Depag RI No. 581 Tahun 1999 mengenai pelaksanaan teknis atas ketersediaan audit laporan keuangan lembaga, juga aturan yang dikeluarkan oleh PSAK (Penyusunan Standar Akuntansi Keuangan) No.109, seharusnya dengan adanya aturan-aturan tesebut, pengelolaan zakat yang dilakukan oleh organisasi pengelola zakat, baik Badan Amil Zakat (BAZ) maupun Lembaga Amil Zakat (LAZ) diharapkan bisa lebih baik, sehingga kepercayaan masyarakat muzaki kepada organisasi pengelola zakat dapat meningkat. Ternyata regulasi belum bisa meyakinkan publik bahwa pengelolaan keuangan LAZ sudah dilakukan dengan semestinya.

\section{Metode Penelitian}

Objek dalam penelitian ini adalah masyarakat kota Bandung yang dipilih secara acak, baik yang pernah membayar zakat melalui LAZ ataupun yang belum pernah membayar zakat melalui LAZ. Masyarakat dimintai pendapat mengenai persepsi masingmasing tentang akuntabilitas dan transparansi LAZ dan pengaruh dari persepsi tersebut terhadap pembayaran zakat melalui LAZ.

Metode yang digunakan dalam penelitian ini adalah penelitian deskriptif kualitatif, yaitu penelitian yang bertujuan untuk memberikan penjelasan mengenai fenomena yang terjadi pada masa sekarang, serta untuk menggambarkan secara sistematis, faktual dan akurat mengenai fakta-fakta atau sifat-sifat dan hubungan antara fenomena yang diteliti. Tema penelitian mengangkat masalah pelaksanaan akuntabilitas dan transparansi laporan keuangan pada Lembaga amil zakat yang ada di Bandung dan beberapa organisasi pengelola zakat lainnya.

Desain penelitian yang digunakan adalah Research Reflexivity yaitu menjelaskan aspek ontologi, epistimologi dan asumsi tipe manusia yang digunakan dalam penelitian. Penelitian ini menjelaskan aspek ontologi yaitu apa yang 
dimaksud dengan akuntabilitas dan transparansi laporan keuangan, kemudian aspek epistimologi yaitu bagaimana laporan keuangan yang diterbitkan oleh LAZ dapat menjawab semua pertanyaan dan memberikan informasi yang diperlukan oleh stakeholder.

Jenis data yang dikumpulkan peneliti dalam penelitian ini terdiri dari data primer dan sekunder. Data primer diperoleh langsung melalui wawancara mendalam (in depth interview) terhadap para informan yang berupa kata-kata maupun tindakan, sedangkan data sekunder berasal dari dokumen-dokumen perusahaan yang dapat dipublikasikan.

Didalam penelitian ini, peneliti merupakan instrument kunci yang sesuai dengan karakteristik penelitian kualitatif. Untuk itu penulis secara individu akan turun ke tengahtengah masyarakat guna memperoleh data dari informan. Pemilihan informan dilakukan secara purposive, yaitu atas dasar apa yang kita ketahui tentang variasi-variasi yang ada (Sanapiah, 1990). Adapun yang menjadi informan adalah lembaga amil zakat, baik yang sudah professional maupun yang belum professional, dan masyarakat kota Bandung yang dipilih secara acak.

Penentuan informan di atas didasarkan pada pendapat Spradley dalam Sanapiah (1990) yang menyatakan bahwa informan adalah mereka yang terlibat langsung dalam aktivitas yang menjadi objek perhatian. Selanjutnya kegiatan pengumpulan data dalam penelitian ini dilakukan dengan mengikuti pola yang dikemukakan oleh Miles dan Huberman (1992) dalam sugiyono (2009), yakni melalui: Wawancara, Observasi, Studi kepustakaan.

Tujuan analisis data adalah mengendalikan data agar sistematis dan sesuai dengan perumusan masalah. Pada penelitian ini, penulis menggunakan analisis data secara induktif yaitu proses analisis yang diawali dengan observasi data, pembahasan, dukungan pembuktian, dan diakhiri dengan kesimpulan.

\section{Hasil Penelitian dan Pembahasan}

Masyarakat yang merasa puas dengan kinerja LAZ, akan memberikan tanggapan positif saat diminta pendapat mengenai kinerja LAZ saat ini, sedangkan masyarakat yang merasa belum puas dengan kinerja LAZ yang ada akan memberikan keluhan mengenai kekurangan tersebut. Pasalnya saat ini tidak semua lapisan masyarakat kenal akrab dengan LAZ, sehingga tidak mudah melakukan penilaian berdasarkan pemahaman masyarakat. Namun ketidakakraban antara masyarakat dengan LAZ itu dapat memberikan jawaban yang objektif dari segi informan. Sebelum masyarakat menilai bagaimana akuntabilitas dan transparansi LAZ, terlebih dahulu dipaparkan bagaimana pemahaman masyarakat mengenai akuntabilitas dan transparansi. Setelah dilakukan penelitian, dapat disimpulkan bahwa masyarakat memiliki pandangan yang sama tentang akuntabilitas dan transparansi, akuntabilitas merupakan sebuah pertanggungjawaban dari lembaga atas laporan keuangan yan telah disusun, termasuk juga di dalamnya ketepatan waktu penyampaian laporan keuangan, dan keandalan dari laporan keuangan itu sendiri. Sedangkan transparansi adalah keterbukaan dari laporan keuangan tersebut, bagaimana sebuah perusahaan mempublikasikan laporan keuangan yang telah disusun sehingga dapat digunakan oleh semua pengguna laporan keuangan.

Dari berbagai pemaparan hasil wawancara sebagian informan mengatakan bahwa akuntabilitas dan transparansi LAZ berpengaruh terhadap penerimaan zakat, sedangkan sebagian informan yang lain mengatakan bahwa hal tersebut tidak berpengaruh terhadap penerimaan zakat oleh LAZ. Meskipun demikian, sebagian besar informan sepakat bahwa pengaruh pandangan masyarakat tidak begitu besar berdampak pada realisasi penerimaan zakat oleh LAZ. 
Pandangan masyarakat terhadap akuntabilitas dan transparansi LAZ terbentuk berdasarkan hasil interaksi antara masyarakat dan LAZ. Pandangan masyarakat lahir, yakni dari interaksi yang terjadi antara masyarakat (baik muzakki maupun mustahik) dengan LAZ yang ada disekitar mereka. Hubungan timbal balik yang terjadi antara masyarakat dan LAZ akan menghasilkan sebuah pengalaman, dari pengalaman tersebut seseorang dapat memberikan penilaian tentang obyek yang berinteraksi dengannya, dalam hal ini LAZ dapat menilai bagaimana potensi ZIS masyarakat dan bagaimana caranya agar membuat masyarakat tertarik untuk membayarkan zakatnya melalui LAZ, sedangkan masyarakat dapat memberikan penilaian berdasarkan pengalaman yang pernah dialami dalam kegiatannya berinteraksi dengan LAZ baik sebagai muzakki maupun sebagai mustahik.

Berdasarkan fakta dan data yang telah disebutkan dalam latar belakang terbentuk hipotesa sementara yang terdiri dari beberapa faktor, yaitu pandangan masyarakat dan pengaruh dari pandangan itu sendiri yang jika digambarkan dengan dengan bagan akan muncul ilustrasi sebagai berikut:

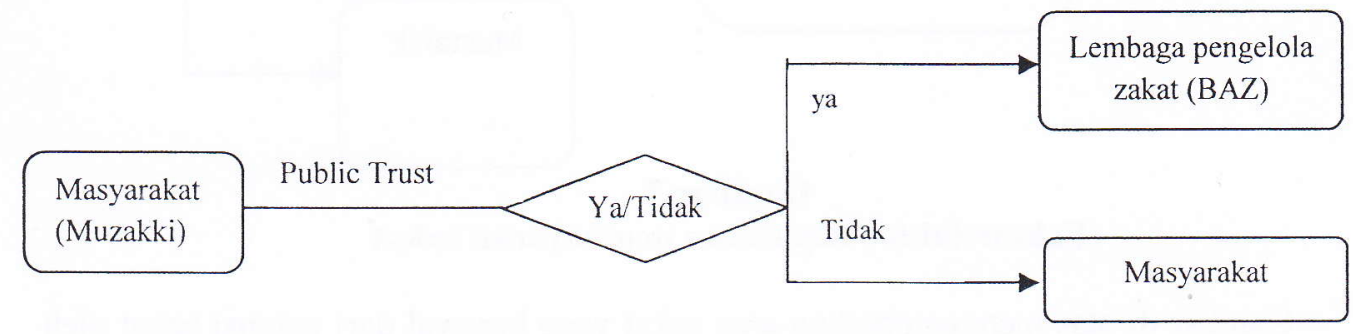

\section{Gambar 1 \\ Hipotesis Awal}

Ilustrasi di atas merupakan hipotesa awal yang menggambarkan bahwa pandangan masyarakat tentang akuntabilitas dan transparansi laporan keuangan LAZ merupakan salah satu faktor yang mempengaruhi minat masyarakat dalam menyalurkan zakatnya melalui LAZ. Hipotesa ini muncul berdasarkan fakta-fakta yang telah disebutkan pada Latar Belakang, dimana terjadi ketimpangan yang cukup besar antara potensi dengan realisasi penerimaan zakat oleh LAZ.

Namun setelah dilakukan wawancara dengan beberapa informan, penulis telah menemukan sebuah titik temu, bahwa pandangan masyarakat tersebut tidak berpengaruh terhadap penerimaan zakat oleh LAZ. Ada faktor-faktor lain yang mempengaruhi keputusan masyarakat dalam menyalurkan LAZ nya, entah itu melalui LAZ atau disalurkan langsung ke mustahik. faktor-faktor tersebut menjadi alasan bagi masyarakat kemana akan menyalurkan zakatnya. Faktor-faktor yang mempengaruhi keputusan masyarakat dalam membayarkan zakatnya antara lain digambarkan sebagai berikut: 


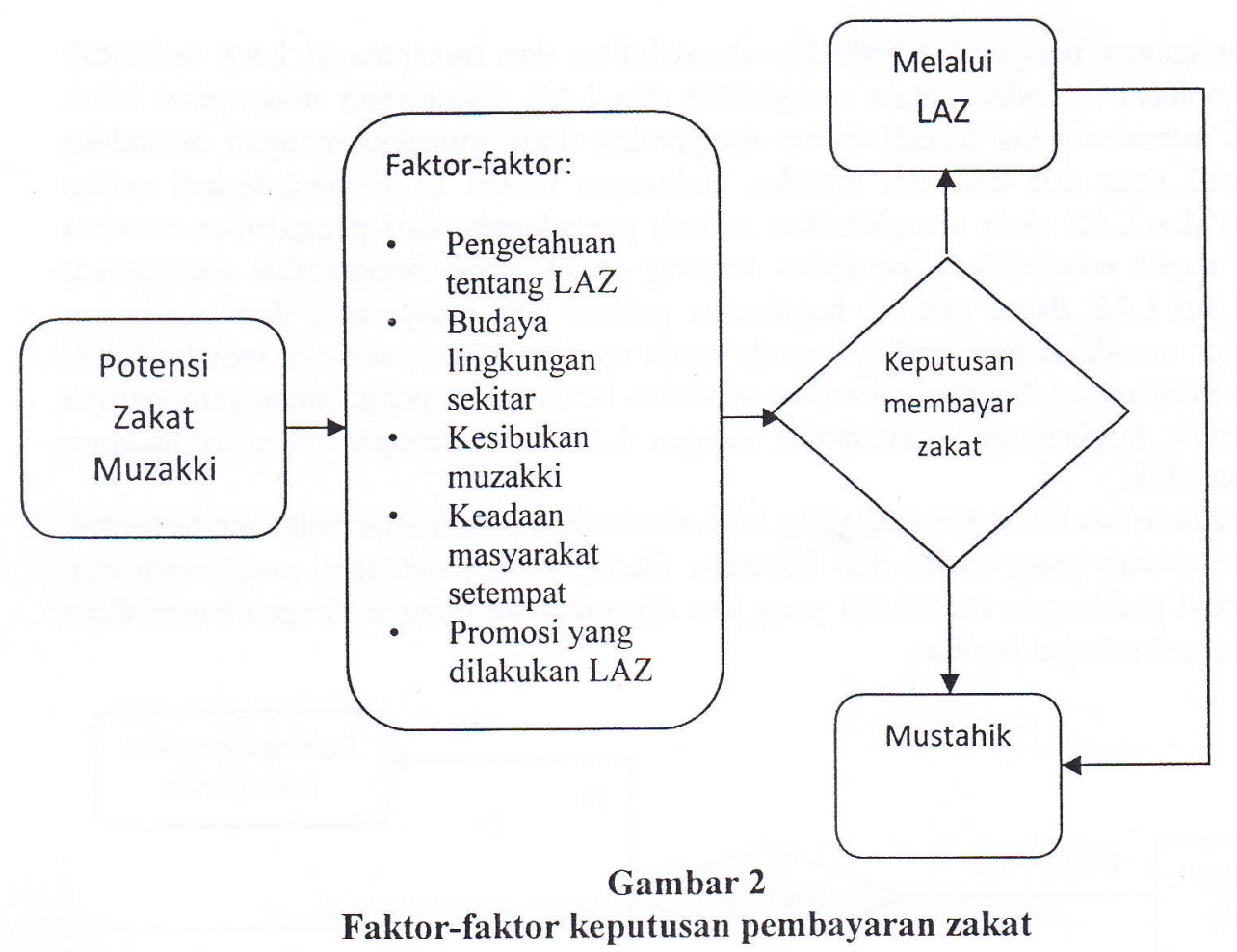

Gambar di atas menggambarkan arus zakat yang berawal dari potensi zakat oleh masyarakat yang kemudian dipengaruhi oleh faktor-faktor yang telah disebutkan. Faktor pertama yakni pengetahuan masyarakat tentang LAZ. Pengetahuan masyarakat tentang LAZ dipengaruhi oleh transparansi LAZ itu sendiri, saat masyarakat mengetahui seperti apa LAZ, kinerjanya bagaimana, program kerjanya apa saja, masyarakat akan mempertimbangakan apakah ia akan membayarkan zakatnya melalui LAZ atau tidak.

Faktor kedua adalah budaya masyarakat setempat masyarakat dalam kehidupan sosialnya melakukan interaksi satu sama lain yang kemudian membentuk pola kehidupan, kebiasaan masyarakat setempat menyalurkan zakat melalui apa, akan menular ke masyarakat sekitar, karena melalui interaksi tersebut, mereka menerima dan memberikan informasi tentang penyaluran zakat warga sekitar, dan akhirnya meniru pola yang ada.

Faktor ketiga yaitu adanya kesibukan muzakki yang membuatnya mengambil keputusan membayar zakat kemana, misalnya seperti salah satu informan Ibu Lina, beliau memiliki kesibukan yang membuat beliau tidak sempat menemukan mustahik, akhirnya zakat yang dibayarkan ditransfer langsung melalui rekening salah satu LAZ yang bekerja sama dengan perusahaannya.

Faktor terakhir yang mempengaruhi keputusan masyarakat dalam membayarkan zakatnya adalah kondisi masyarakat sekitar. Jika kita melihat ada tetangga yang pengahasilannya masih kurang dalam memenuhi kebutuhan hidupnya, sudah pasti kita akan memberikan zakat tersebut ke orang terdekat, hal ini sesuai dengan Al-Qur'an Surat Al-Isra' ayat 26, yang artinya: "dan berikanlah haknya kepada kerabat dekat, juga kepada orang miskin dan orang yang dalam perjalanan; dan janganlah kamu mengahamburhamburkan (hartamu) secara boros"

Orang terdekat yang dimaksud adalah keluarga dan orang-orang yang ada disekitar kita. Bagi masyarakat yang tinggal didaerah yang tingkat perekonomiannya bersifat homogen, biasanya muzakki memilih membayar zakanya melalui LAZ, sedangkan yang bersifat heterogen tingkat perekonomiannya, biasanya masyarakat akan 
melihat keadaan tetangga disekitar rumah, barulah memutuskan akan membayarkan zakatnya kemana.

Indikator keberhasilan transparansi antara lain: (1) Meningkatnya keyakinan dan kepercayaan publik kepada LAZ, bahwa LAZ merupakan lembaga yang bersih dan amanah; (2) Meningkatnya partisiasi publik dalam penyelenggaraan kegiatan LAZ; (3) Bertambahnya wawasan dan pengetahuan publik tentang pengelolaan zakat oleh LAZ; (4) Pengelolaan zakat yang sesuai dengan UU yang berlaku.

Berikut ini tabel yang menunjukkan tentang persepsi masyarakat dengan indikator akuntabilitas yang ada:

Tabel 4

Tanggapan informan mengenai Akuntabilitas LAZ dalam mengelola Dana Zakat

\begin{tabular}{|l|l|l|}
\hline No & \multicolumn{1}{|c|}{ Item Idikator } & \multicolumn{2}{|c|}{ Penilaian } \\
\hline $\mathbf{1 .}$ & $\begin{array}{l}\text { Indikator kinerja LAZ dalam } \\
\text { menyalurkan Dana zakat dirasa } \\
\text { optimal }\end{array}$ & $\begin{array}{l}\text { Sebagian besar masyarakat menilai } \\
\text { bahwa penyaluran zakat oleh LAZ } \\
\text { cukup optimal. }\end{array}$ \\
\hline $\mathbf{2 .}$ & $\begin{array}{l}\text { Indikator laporan keuangan yang telah } \\
\text { dipublikasikan dapat memberikan } \\
\text { informasi yang dibutuhkan para } \\
\text { pengguna laporan keuangan }\end{array}$ & $\begin{array}{l}\text { Masyarakat yang pernah melihat laporan } \\
\text { keuangan LAZ yang dipublikasikan } \\
\text { melalui buletin puas dengan informasi } \\
\text { yang diberikan dalam laporan tersebut. }\end{array}$ \\
\hline $\mathbf{3 .}$ & $\begin{array}{l}\text { Indikator dilakukan audit independen } \\
\text { terhadap laporan keuangan yang telah } \\
\text { disusun }\end{array}$ & $\begin{array}{l}\text { Sebagian besar LAZ profesional seperti } \\
\text { Mizan Amanah, RZI, dan lainnya telah } \\
\text { melakukan audit independen. }\end{array}$ \\
\hline $\mathbf{4 .}$ & $\begin{array}{l}\text { Indikator penempatan karyawan yang } \\
\text { sesuai dengan kemampuan serta latar } \\
\text { belakang pendidikan yang dimiliki }\end{array}$ & $\begin{array}{l}\text { Penempatan karyawan masih belum } \\
\text { disesuaikan dengan latar belakang } \\
\text { pendidikan, SDM nya masih terbatas }\end{array}$ \\
\hline $\mathbf{5 .}$ & $\begin{array}{l}\text { Indikator penerapan pedoman standar } \\
\text { laporan keuangan berdasarkan PSAK } \\
\text { 109 }\end{array}$ & $\begin{array}{l}\text { Tidak semua LAZ menerapkan PSAK } \\
\text { 109, karena masih dalam masa } \\
\text { penyesuaian }\end{array}$ \\
\hline
\end{tabular}

Sedangkan indikator transparansi berdasarkan hasil penelitian yang dilakukan disajikan dalam tabel berikut ini:

Tabel 5

Tanggapan informan mengenai Transparansi LAZ dalam mengelola Dana Zakat

\begin{tabular}{|l|l|l|}
\hline No & \multicolumn{1}{|c|}{ Item Idikator } & \multicolumn{1}{|c|}{ Penilaian } \\
\hline $\mathbf{1 .}$ & $\begin{array}{l}\text { Indikator LAZ cukup terbuka dalam } \\
\text { memberikan informasi mengenai pengelolaan } \\
\text { zakat }\end{array}$ & $\begin{array}{l}\text { Hal ini bergantung pada kebijakan } \\
\text { LAZ, namun sebagian besar } \\
\text { masyarakat mengatakan mereka } \\
\text { cukup terbuka }\end{array}$ \\
\hline $\mathbf{2 .}$ & $\begin{array}{l}\text { Indikator masyarakat mengetahui penyaluran } \\
\text { distribusi zakat yang dilakukan oleh OPZ }\end{array}$ & $\begin{array}{l}\text { Masyarakat yang membayarkan } \\
\text { zakatnya melalui LAZ mengetahui } \\
\text { kemana dana dialirkan, }\end{array}$ \\
\hline $\mathbf{3 .}$ & $\begin{array}{l}\text { Indikator LAZ terbuka mengenai laporan } \\
\text { keuangannya kepada masyarakat }\end{array}$ & $\begin{array}{l}\text { Tidak semua masyarakat puas } \\
\text { dengan keterbukaan LAZ } \\
\text { mengenai laporan keuangan }\end{array}$ \\
\hline 4. & $\begin{array}{l}\text { Indikator laporan keuangan yang diberikan } \\
\text { memberikan pengaruh kepercayaan } \\
\text { masyarakat }\end{array}$ & $\begin{array}{l}\text { Sebagian masyarakat merasa } \\
\text { bahwa laporan keuangan yang } \\
\text { diberikan merupakan bukti dari } \\
\text { transparansi laporan keuangan }\end{array}$ \\
\hline
\end{tabular}


Tanggapan masyarakat mengenai transaparansi laporan keuangan LAZ ini berdasarkan atas pengetahuan masyarakat tentang LAZ. Semakin transparan sebuah LAZ, semakin banyak pengetahuan masyarakat tentangnya dan semakin banyak pula informasi yang dapat digali dari masyarakat mengenai pendapat mereka tentang LAZ. Sebagian besar masyarakat memberikan tanggapan positif mengenai kebijakan-kebijakan yang dilakukan oleh LAZ.

\section{Simpulan}

Berdasarkan hasil penelitian mengenai "Akuntabilitas dan Transparansi Laporan Keuangan Lembaga Amil Zakat di kota Bandung", maka peneliti menarik kesimpulan sebagai berikut:

1. Masyarakat menilai bahwa lembaga zakat profesional sudah menerapkan prinsip akuntabilitas. Pendayagunaan zakat produktif dan laporan keuangan yang disusun mudah dipahami oleh masyarakat menunjukkan bahwa kualitas informasi dalam laporan tersebut memberikan manfaat bagi pengguna laporan keuangan dalam mengambil keputusan, akan tetapi transparansinya dinilai kurang, karena berdasarkan hasil observasi yang dilakukan oleh peneliti tidak semua LAZ menghendaki adanya kemudahan akses informasi kepada masyarakat secara umum, dibeberapa LAZ laporan keuangan yang telah disusun hanya dapat diakses oleh donatur.

2. Sebagian besar masyarakat yang tidak membayarkan zakat melalui LAZ mengatakan bahwa alasan mereka tidak membayarkan zakat melalui LAZ bukanlah karena ketidakpercayaan mereka terhadap akuntabilitas dan transparansi LAZ, melainkan adanya faktor-faktor lain yang lebih mempengaruhi, seperti faktor lingkungan sekitar tempat tinggal dan promosi yang dilakukan oleh LAZ. Hal ini membuktikan bahwa akuntabilitas dan transparansi laporan keuangan LAZ tidak menjadi pertimbangan utama bagi masyarkat dalam menyalurkan zakat.

\section{Daftar Pustaka}

Al-Qur'an. Terjemahan Departemen Agama R.I

Annisaningrum. (2010) Akuntabilitas dan Transparansi dalam Laporan Keuangan. [Online]. Tersedia: http://annisaningrum.blogspot.com/2010/07/akuntabilitasdan-transparansi-dalam.html [5 Agustus 2011]

Departemen Agama Republik Indonesia. (1999). Keputusan Menteri Agama Republik Indonesia Nomor 581 Tahun 1999 tentang Pelaksanaan Undang-Undang Nomor 38 Tahun 1999 tentang Pengelolaan Zakat. Jakarta: Depag RI.

Dewan Standar Akuntansi Keuangan. (2012) Pernyataan Standar Akuntansi Keuangan 109 "Akuntansi Zakat dan Infak/ Sedekah"

Faisal, Sanapiah. (1990). Penelitian Kualitatif, Dasar-dasar dan Aplikasi. Malang: Yayasan Asih Asah Asuh

Didin, Hafhifuddin,. (2002). Zakat dalam Perekonomian Modern. Jakarta: Gema Insani.

Sofyan Syafri, Harahap(2008). Analisis Kritis atas Laporan Keuangan. Jakarta: Raja Grafindo Persada

Ine Dwiyanti. (2007) Akuntabilitas Lembaga Amil Zakat. Sebuah Studi Deskriptif Causalitatif. [Online]. Tersedia: http://demustaine.blogdetik.com/2007/08/24/akuntabilitas-lembaga-amil-zakat/ [5 Agustus 2011] 
Iwan, Triyuwono, 2000, Konsistensi Praktik Sistem Pengendalian Intern dan Akuntabilitas pada Lazis, Jurnal Riset Akuntansi Indonesia, Vol 3, No.2

Josephus Primus. (2008). Potensi Zakat Rp 9 Triliun . [Online]. Tersedia: http://nasional.kompas.com/read/2008/06/04/14202696/potensi.zakat.rp9.miliar [5 Agustus 2011]

Nidya Pusparini. (2010). Pengaruh Penyajian Laporan Keuangan Berdasarkan PSAK Nomor 45 terhadap Akuntabilitas dan Transparansi Laporan Keuangan (Survei pada Lembaga Amil Zakat di Kota Bandung). Skripsi. Bandung: Universitas Pendidikan Indonesia.

Siti Muniroh. (2008). Akuntabilitas Persepsi Masyarakat terhadap Badan Amil Zakat (Studi Kasus di Desa Sambung Kecamatan Undaan Kabupaten Kudus). Tesis. Semarang: IAIN Walisongo.

Sugiyono. (2009). Metode Penelitian Kuantitatif Kualitatif dan R\&D. Bandung: Alfabeta. Undang-undang Republik Indonesia Nomor 38 Tahun 1999 tentang Pengelolaan Zakat. (2008). Zakat \& Empowering-Jurnal Penelitian dan Gagasan, Volume 1, Nomor 4. CID. [Online]. Tersedia: http://zakat.or.id/category/jurnal-ziswaf// [13 Mei 2011] 